\title{
Localization of Ang-1, -2, Tie-2, and VEGF expression at endothelial-pericyte interdigitation in rat angiogenesis
}

\author{
Shin Wakui ${ }^{1}$, Kiyofumi Yokoo ${ }^{1}$, Tomoko Muto ${ }^{2}$, Yoshihiko Suzuki ${ }^{3}$, Hiroyuki Takahashi ${ }^{4}$ \\ Masakuni Furusato ${ }^{5}$, Hiroshi Hano ${ }^{4}$, Hitoshi Endou ${ }^{2}$ and Yoshikatsu Kanai ${ }^{2}$ \\ ${ }^{1}$ Department of Toxicologic Pathology, Azabu University School of Veterinary Medicine, Kanagawa, Japan; \\ ${ }^{2}$ Department of Pharmacology and Toxicology, Kyorin University School of Medicine, Tokyo, Japan; \\ ${ }^{3}$ Department of Biochemistry, Azabu University School of Veterinary Medicine, Kanagawa, Japan; \\ ${ }^{4}$ Department of Pathology, The Jikei University School of Medicine, Tokyo, Japan and ${ }^{5}$ Department of \\ Pathology, Kyorin University School of Medicine, Tokyo, Japan
}

\begin{abstract}
Endothelial cells and pericytes play critical role in angiogenesis, which is controlled, in part, by the angiopoietin (Ang)/Tie-2 system and vascular endothelial growth factor (VEGF). Here, we investigated Ang, Tie-2, and VEGF expression within endothelial cells and pericyte interdigitations (EPI), which consist of cytoplasmic projections of pericytes and corresponding endothelial indentations. After subcutaneous implantation of a thermoreversible gelation polymer disc in rats, the capillary density was low on day 5 , increased to a peak on day 7 , and then decreased on days 10-20. A small number of EPI were observed on day 5, then increased sharply to a peak on day 10, but had decreased on day 20. Light and electron microscopy immunohistochemical and RNA in situ hybridization analyses revealed that Tie-2 localized at endothelial cells, and Ang-2 localized at endothelial cells and pericytes, while Ang-1 and VEGF localized at pericytes, and Ang-1 was most intensely observed at EPI of pericytes. Conventional quantitative RT-PCR and Western blot analyses revealed that the level of Ang-1 was low on days 5-7, then increased on days 10-20, while the level of VEGF was high on days 5-10, but had decreased on day 20. The level of Ang-2 remained high and Tie-2 remained at the level of the control on days 5-20. The present study showed that the angiogenic phase might be initiated by increases in Ang-2 and VEGF, while the microvessel maturation phase might be initiated by a relative increase in Ang-1 and a decrease in VEGF. Moreover, EPI might serve as a pathway for the Ang-1/Tie-2 system, with VEGF promoting pericyte recruitment for microvascular integrity.

Laboratory Investigation (2006) 86, 1172-1184. doi:10.1038/labinvest.3700476; published online 11 September 2006
\end{abstract}

Keywords: Ang-1; Ang-2; Tie-2; VEGF; angiogenesis; EPI

Angiogenesis, the growth of new vessels from preexisting blood vessels, requires complex multistep signaling pathways and a high degree of spatial and temporal coordination among endothelial cells and pericytes. The precise mechanisms at the cellular and molecular levels are not completely defined., ${ }^{1,2}$ Despite their recognized importance in angiogenesis, pericytes have received less attention than endothelial cells, and their functions are only now beginning to be understood. ${ }^{3-7}$ Pericytes share the

Correspondence: Dr S Wakui, DVM, PhD, Department of Toxicologic Pathology, Azabu University School of Veterinary Medicine, 1-17-71 Fuchinobe, Sagamihara, Kanagawa 229-8501, Japan.

E-mail: wakui@azabu-u.ac.jp

Received 31 May 2006; revised 14 August 2006; accepted 15 August 2006; published online 11 September 2006 basement membrane with endothelial cells and come into contact with them through holes in the basement membrane. Large numbers of ultrastructural endothelial cell and pericyte cytoplasmic interdigitations (EPI) are frequently demonstrated in angiogenic sites of human and murine tissues. ${ }^{8-15}$ These consist of a combination of pericyte cytoplasmic projections and corresponding indentations in the adjacent endothelial cells. ${ }^{8-15}$ In EPI, there is a distinctive gap measuring from 15 to $30 \mathrm{~nm}$ in width between endothelial cells and pericytes. ${ }^{8,9,14}$ While it has been suggested that EPI might be a mechanical anchoring system for the two cells, ${ }^{16-18}$ we have shown that the intercellular EPI space lacks adhesive glycoproteins, including fibronectin and laminin. ${ }^{9,11}$ Moreover, we have shown that plasmalemmal pits and vesicles are frequently present in the endothelial cells at EPI, ${ }^{9}$ and have demonstrated 
that epidermal growth factor, ${ }^{12}$ transforming growth factor-beta, plasminogen, and urokinase plasminogen activator are present in the intercellular EPI space. $^{19}$

The intercellular signaling mechanisms that govern the formation of blood vessels have only recently begun to be studied at the molecular level. Many growth factors are proposed to play a role in angiogenesis. Two types of vascular regulatory molecules that have been the subject of intense investigation in both physiological and pathological blood vessel generation are the angiopoietin (Ang)/ Tie-2 system and vascular endothelial growth factor (VEGF). ${ }^{20-30}$ Tie-2 is one of the receptor tyrosine kinases that are expressed by vascular endothelial cells, ${ }^{21,31,32}$ and Ang-1 and -2, the ligands for Tie-2, have been reported to be important in the development of microvessels. ${ }^{33-35}$ Ang- 1 induces the autophosphorylation of Tie-2 in cultured endothelial cells, ${ }^{22}$ and it has been proposed that Ang-1 recruits pericytes and potentiates microvessel stabilization and maturation by supporting interactions between endothelial cells and pericytes; however, the detailed biological character of pericytes is unclear. ${ }^{33-36}$ Ang-2 acts as an antagonist and inhibits Ang-1induced phosphorylation of Tie-2 receptors in endothelial cells; as a result, Ang-2 initiates extensive angiogenesis resulting in pericyte drop-off and vascular destabilization. ${ }^{2-25,29,33,37-39}$

The nature of cell-cell interactions such as EPI that occur during vessel formation and their mediators is difficult to discern from in vivo studies. Based on the distinct functions of Ang-1 and -2, we hypothesized that EPI are involved in the Ang/Tie2 system at angiogenic sites. In the present study, as an initial step toward the goal of understanding angiogenesis, we examined the formation of EPI, and the expression and localization of Ang-1, -2, Tie-2, and VEGF in rats subcutaneously implanted with a thermoreversible gelation polymer (TGP) disc, a three-dimensional culture medium gel $^{40}$ angiogenic disc model. The present study gives the first indication that Ang-1 may play a role in EPI by recruiting pericytes to support the primitive endothelial tubule and enhance microvessel maturation.

\section{Materials and methods}

\section{Experimental Model}

Forty male 7-week-old Sprague-Dawley (slc) rats (Japan SLC, Shizuoka, Japan) were housed, two per plastic cage, on hardwood-chip bedding in an environment-controlled room on a 12-h light/12-h dark cycle at $22 \pm 2{ }^{\circ} \mathrm{C}$ and $55 \pm 5 \%$ relative humidity with a conventional diet (MF, Oriental Yeast, Tokyo, Japan). All experimental procedures were conducted following approval of the Animal Care and Use Committee of the Azabu University School of Veterinary Medicine. Guidelines set by the National Institute of Health and Public Health Service Policy on the Humane Use and Care of Laboratory Animals were followed at all times. We used TGP (Mebiol Inc., Kanagawa, Japan) without additional any growth factors for the experimental angiogenic model. ${ }^{40}$ TGP is a thermoreversible hydrogel comprising a copolymer of poly( $N$-isopropylacrylamide) and poly(ethylene glycol). ${ }^{41,42}$ The sterilized TGP discs were cut into circles measuring $14 \mathrm{~mm}$ in diameter and $2 \mathrm{~mm}$ in thickness, and were implanted subcutaneously in the rat through a far away skin incision. The discs were removed from 10 rats each $5,7,10$, and 20 days after implantation and examined.

\section{Electron Microscopy}

Specimens were fixed in $0.1 \mathrm{M}$ phosphate-buffered $1.2 \%$ glutaraldehyde for $2 \mathrm{~h}$ and then postfixed in $1.0 \%$ osmium tetroxide for $2 \mathrm{~h}$. After dehydration in graded alcohols, the specimens were embedded in Epon 812. Thin sections were cut on a Porter-Blum MT-II ultramicrotome and mounted on formvarcoated slit grids. After double staining with uranyl acetate and lead citrate, the sections were observed with a Hitachi $\mathrm{H}-500 \mathrm{H}$ electron microscope. In order to limit our studies to newly formed capillaries within each sample, only the centers of the discs were sampled. The morphometry of cross-sectioned vessels was analyzed, and those having a length-towidth ratio of less than two were used. ${ }^{14}$ Ten to 20 blood capillaries (not larger than $15 \mu \mathrm{m}$ diameter, following the description by Leeson et $a)^{43}$ were photographed randomly from each of 10 different specimen blocks from each disc. The number of EPI per capillary, the number of capillaries per $1 \mathrm{~mm}^{2}$, the outer diameters of the capillaries, and the number of endothelial cells and pericytes per capillary on the electron micrographs were counted. The number of nuclei defined the endothelial cells and pericytes.

\section{Immunohistochemistry for Light Microscopy}

Immunohistochemical expressions of Ang-1, -2, Tie-2, and VEGF were analyzed using the avidin-biotin complex (ABC) method. After deparaffinization, $4-\mu \mathrm{m}$-thick sections were treated sequentially with $0.3 \% \mathrm{H}_{2} \mathrm{O}_{2}$ for $10 \mathrm{~min}$, then blocked with $10 \%$ goat serum or rabbit serum in PBS for $20 \mathrm{~min}$. Frozen sections were thawed, rinsed in PBS, and treated with primary antibodies of Ang-1 (N-18) sc-6319 goat polyclonal IgG (Santa Cruz Biotech, CA, USA; diluted 1:500), Ang-2 (F-18) sc-7017 goat polyclonal IgG (Santa Cruz Biotech; diluted 1:500), Tie-2 (H-167) sc-9026 rabbit polyclonal IgG (Santa Cruz Biotech; diluted 1:500), or VEGF (147) sc-507 rabbit polyclonal IgG (Santa Cruz Biotech; diluted 1:500). Bound IgG was detected with biotinylated goat antigoat IgG (Vector Lab., CA, USA; diluted 1:100) or anti-rabbit IgG (Vector Lab.; diluted 1:100), followed 
by ABC-peroxidase (Vector Lab.) and diaminobenzidine (Sigma-Aldrich, MO, USA). Sections were then counterstained with hematoxylin. As a negative control, nonimmunized rabbit serum was substituted for the primary antibody.

\section{Immunohistochemistry for Electron Microcopy}

An indirect enzyme immunohistochemical of preembedded method was used. ${ }^{44}$ Specimens were fixed in PLP solution ${ }^{44}$ for $6 \mathrm{~h}$, washed in graded sucrose solutions in $0.1 \mathrm{M}$ phosphate-buffered saline, and frozen. Frozen sections were cut on a cryostat at a thickness of $6 \mu \mathrm{m}$ and mounted on PLLcoated glass slides. The sections were incubated at $4^{\circ} \mathrm{C}$ in a humidified chamber for $12 \mathrm{~h}$ with a primary antibody for Ang-1 (N-18) sc-6319 goat polyclonal IgG (Santa Cruz Biotech; diluted 1:100), Ang-2 (F-18) sc-7017 goat polyclonal IgG (Santa Cruz Biotech; diluted 1:100), Tie-2 (H-167) sc-9026 rabbit polyclonal IgG (Santa Cruz Biotech; diluted 1:200), or VEGF (147) sc-507 rabbit polyclonal IgG (Santa Cruz Biotech; diluted 1:200). Peroxidase-conjugated rabbit $\mathrm{F}\left(\mathrm{ab}^{\prime}\right)^{2}$ to goat IgG (ICN/Cappel Inc., OH, USA; diluted 1:100) or peroxidase-conjugated rabbit $\mathrm{F}\left(\mathrm{ab}^{\prime}\right)^{2}$ to rabbit IgG (ICN/Cappel Inc.; diluted $1: 100)$ was used as the secondary antibody and incubated for $8 \mathrm{~h}$. Then sections were immersed in Tris-HCl-buffered $0.02 \% 3,3^{\prime}$-diaminobenzidine tetrahydrochloride (DAB) containing $0.1 \mathrm{M}$ sodium azide and $0.005 \%$ hydrogen peroxidase for 36 min. A control section was stained using rabbit or goat preimmune serum without the corresponding primary antibody and processed as described above. For electron microscopy, sections were postfixed with $1.0 \%$ osmium tetroxide for $1 \mathrm{~h}$ and embedded in Epon 812. Ultrathin sections were cut on a Porter-Blum ultramicrotome and were mounted on Formvar-coated slit grids. The sections were observed with a Hitachi $\mathrm{H}-2000$ electron microscope without uranyl acetate and lead citrate staining.

\section{RNA In Situ Hybridization}

mRNA detection was used to prepare digoxigenin (DIG)-labeled antisense and sense probes. DIGlabeled sense probes were used as a negative control. Frozen sections were cut at a thickness of $10 \mu \mathrm{m}$ on a cryostat, fixed with $4 \%$ paraformaldehyde in $0.1 \mathrm{M}$ phosphate buffer ( $\mathrm{pH} 7.4$ ), and permeabilized with $0.01 \mathrm{M}$ sodium citrate and $0.2 \mathrm{M}$ $\mathrm{HCl}$ for $30 \mathrm{~min}$, phosphate-buffered $1 \%$ sodium dodecyl sulfate (SDS) for $5 \mathrm{~min}, 1 \mu \mathrm{g} / \mathrm{ml}$ proteinase $\mathrm{K}$ for $30 \mathrm{~min}$ at $37^{\circ} \mathrm{C}$, and acetylated with $0.1 \mathrm{M}$ triethanolamine containing $0.25 \%(\mathrm{v} / \mathrm{v})$ acetic anhydride. Sections were incubated in hybridization solution, consisting of $1 \times$ Denhardt's solution, $2 \times$ SSC, $10 \%$ dextran sulfate, $50 \%$ formamide, $50 \mu \mathrm{g} / \mathrm{ml}$ yeast tRNA, $1 \mathrm{M}$ DTT, and $1 \mathrm{mg} / \mathrm{ml}$ salmon sperm DNA for $16 \mathrm{~h}$ at $55^{\circ} \mathrm{C}$. After hybridization, sections were rinsed in $2 \times$ SSC at room temperature, then sequentially washed in $2 \times \mathrm{SSC} / 50 \%$ formamide at $55^{\circ} \mathrm{C}$, rinsed in $2 \times \mathrm{SSC}$ at $37^{\circ} \mathrm{C}$, washed twice in $2 \times \mathrm{SSC} / 50 \%$ formamide at $55^{\circ} \mathrm{C}$, and washed three times in $2 \times$ SSC at room temperature. For signal amplification, a horseradish peroxidase-conjugated rabbit anti-digoxigenin antibody (Dako, CA, USA) was used to catalyze the deposition of biotinyltyramide, followed by a secondary streptavidin complex Gen Point kit (Dako). The final signal was visualized by incubation with $\mathrm{DAB}$ and $0.03 \%(\mathrm{v} / \mathrm{v})$ hydrogen peroxide in $0.05 \mathrm{M}$ Tris- $\mathrm{HCl}$ for $20 \mathrm{~min}$, and the sections were counterstained in hematoxylin for $5 \mathrm{~s}$. Antisense probes used for in situ hybridization were Ang-1 (5'-AGCATGGTGGCCGT GTGGTTTTGAACCGCATTCTGTTGTATCT-3'), Ang-2 (5'-CTTGTCGTCTGGTTTAGTACTTGGGCTTCCACA TCAGTCAGTTTCCGAGTTTG-3'), Tie-2 (5'-GCAAC ATAATCAGAAACGCCAATAGCACGGTGATGCAAG TCATTCCAG-3'), and VEGF (5'-TGCGCTGGTAGACGT CCATGAACTTCACCACTTCATGGGCTTTCTGCT-3'); these antisense sequences were complementary to nucleotide mRNA specific to rat. ${ }^{45}$ Probes were chemically synthesized by and DIG-labeled oligonucleotide was obtained from Sigma Genosys (Sigma-Aldrich).

\section{RNA Isolation}

Total RNA was extracted from frozen tissue using a QIA shredding homogenizer and a Qiagen Rneasy Mini Kit (Qiagen Inc., CA, USA). After isolation, the quality of RNA samples was assessed using an Agilent 2100 bioanalyzer (Agilent Technologies Inc., CA, USA) and a RNA 6000 LabChip kit (Agilent Technologies Inc).

\section{Semiquantitative RT-PCR}

cDNA synthesis was performed using random hexamers with the Super Script First-Strand Synthesis kit according to the instructions of the manufacturer (Invitrogen Co., CA, USA). Then, $1 \mu \mathrm{l}$ of the reverse transcription reaction was used for PCR amplification in a volume of $50 \mu \mathrm{l}$ containing genespecific primers for Ang-1, Ang-2, VEGF, Tie-2, and GAPDH. Aliquots of the PCR reaction were removed at different cycles for agarose gel analysis to determine the linear range of amplification. All reactions were run on $2 \%$ agarose gel. The following primers were used: Ang-1 (GenBank AB080023) (fw: 5'-AGCATGT GATGGAAAATTATACT-3'), (rv: $5^{\prime}$-AGTACCTGGGT CTCCACATC-3'); Ang-2 (XM_344544) (fw: 5'-AAC TACATCCAGGACAACAT-3'), (rv: 5'-TATATTGTAGT TTGTTTATTTCACTG-3'); VEGF (NM_031836) (fw: 5'-CTGCTCTCTTGGGTGCACT-3'), (rv: 5'-ATACACT ATCTCATCGGGGTACT-3'); Tie-2 (AF030423) (fw: 5'-GCTGAGAACAACATAGGAT-3'), (rv: 5'-CTGAGT TGAACTGAACAGC-3'); and GAPDH (AF106860) (fw: 5'-CTCTACCCACGGCAAGTTC-3'), (rv: 5'-ACGATGC 
CAAAGTTTCATG-3'). PCR was performed using a 9700 GeneAmp (Applied Biosystems, CA, USA) at $94^{\circ} \mathrm{C}$ for $5 \mathrm{~min}$, followed by 28 cycles of $94^{\circ} \mathrm{C}$ for $1 \mathrm{~min}, 58^{\circ} \mathrm{C}$ for $1 \mathrm{~min}, 72^{\circ} \mathrm{C}$ for $1 \mathrm{~min}$, and finally $72^{\circ} \mathrm{C}$ for $7 \mathrm{~min}$. PCR products were visualized on $2 \%$ agarose gels stained with ethidium bromide. Relative mRNA levels were compared with the corresponding levels of GADPH.

\section{Quantitative RT-PCR}

Real-time RT-PCR reactions were carried out using the cDNA equivalent of $100 \mathrm{ng}$ total RNA for each sample in a total volume of $25 \mu \mathrm{l}$ of TaqMan Universal PCR Master Mix (Applied Biosystems). The thermal cycling program for PCR was $50^{\circ} \mathrm{C}$ for $2 \mathrm{~min}, 95^{\circ} \mathrm{C}$ for $10 \mathrm{~min}$, and 40 cycles of amplification comprising $95^{\circ} \mathrm{C}$ for $15 \mathrm{~s}$, and $60^{\circ} \mathrm{C}$ for $1 \mathrm{~min}$. PCR assay was performed using Assays on Demand Gene Expression Products in an ABI Prism 7700 sequence detector (Applied Biosystems). Gene expressions of Ang-2 (Rn01756774_m1), Tie-2 (Rn01433337_m1), and VEGF (Rn01511607_m1) (Applied Biosystems) were assayed. As a gene expression assay for Ang-1 has not been developed for Assays on Demand (Applied Biosystems), we applied a TaqMan rodent Ang-1 assay using the primers (fw: 5 '-CCATGCTTGAGATAGGAACCAG$\left.3^{\prime}\right), \quad\left(\mathrm{rv}: \quad 5^{\prime}\right.$-TTCAAGTCGGGATGTTTGATTT- $\left.3^{\prime}\right){ }^{46}$ The GAPDH primer was obtained from TaqMan rodent control reagents (Applied Biosystems). Amplification of GAPDH mRNA was performed as the internal gene control to account for variations in RNA levels between different samples. Data were collected and analyzed with Sequence detector v.1.7. The relative quantification method of $\Delta \Delta C_{\mathrm{T}}$ was used as described in the manufacturer's manual (User Bulletin \#2; P/N 4303859, pp 35). ${ }^{47}$ Moreover, normal subcutaneous tissue was designated as the calibrator, and the normalized target gene values were compared to the calibration value according to the manufacturer's instructions for quantification of relative gene expression (User Bulletin \#2; $\mathrm{P} / \mathrm{N}$ 4303859, pp 15, 34). ${ }^{48}$

\section{Western Blot Analysis}

Specimens were homogenized in $50 \mathrm{mM}$ Tris-HCl, $150 \mathrm{mM} \mathrm{KCl} \mathrm{(pH} \mathrm{7.4),} \mathrm{1 \%} \mathrm{Triton} \mathrm{X-100,} \mathrm{and}$ $0.25 \mathrm{mM}$ phenylmethylsulfonyl fluoride and centrifuged at $8000 \mathrm{~g}$ for $30 \mathrm{~min}$ at $4^{\circ} \mathrm{C}$. The pellet was lysed with lysis buffer $(10 \mathrm{mM}$ Tris-HCl, $1 \%$ SDS, $1 \mathrm{mM}$ EDTA, $10 \%$ glycerol, and 5\% 2-mercaptoethanol. The protein concentrations of these lysates were quantified using $4 \mu \mathrm{l}$ in a Protein 200 Lab-chip kit (Agilent Technologies Inc.) and run on an Agilent 2100 Bioanalyzer (Agilent Technologies Inc.). An equal amount of protein $(10 \mu \mathrm{g})$ from each lysate was resolved on $10 \%$ SDS polyacrylamide gels under denaturing conditions and then transferred to Immuno-Blot polyvinylidene difluoride (PVDF) membranes (Bio-Rad Lab., CA, USA). After overnight blocking by immersion in $5 \%$ non-fat dried milk in phosphate-buffered saline with $0.1 \%(\mathrm{v} / \mathrm{v})$ Tween 20 (PBS-T), Western blot analysis was performed using antibodies to Ang-1 (N-18) sc6319 goat polyclonal IgG (Santa Cruz Biotech; diluted 1:1000), Ang-2 (F-18) sc-7017 goat polyclonal IgG (Santa Cruz Biotech; diluted 1:1500), Tie-2 (H-167) sc-9026 rabbit polyclonal IgG (Santa Cruz Biotech; diluted 1:2000), VEGF (147) sc-507 rabbit polyclonal IgG (Santa Cruz Biotech; diluted 1:1000), and beta-actin polyclonal IgG (Santa Cruz Biotech; diluted 1:4000) in PBS-T and incubated $1 \mathrm{~h}$ at room temperature on an orbital shaker. After being washed three times with PBS-T, the membranes were incubated with a 1:2500 dilution of peroxidase-conjugated goat IgG (ICN/Cappel Inc.) or peroxidase-conjugated rabbit IgG (ICN/Cappel Inc.) for $1 \mathrm{~h}$ on an orbital shaker. After being washed three times with PBS-T, the membranes were detected using the ECL Plus Western Blotting Detection System (Applied Biosystems). To verify the relative amounts of protein in each lane, the levels of beta-actin were determined as an internal control.

\section{Statistical Analysis}

For each data set, the mean value, s.d., and s.e.m. were calculated and compared by Scheffé's $F$-test using the statistical analysis program Stat View-J 5.0 (Abacus Concepts, NC, USA).

\section{Results}

\section{General Characteristics of Newly Formed Capillaries in TGP Discs}

Microvascular growth in the TGP disc proceeded in a centripetal direction. The angiogenic process was preceded by fibrovascular granulation tissues, consisting of capillary endothelial cells, pericytes, fibroblasts, and vacuolated fibroblasts, and was almost free from migrating inflammatory cells (Figures 1 and 2).

On days 5-7, newly formed capillaries were morphologically composed of immature endothelial cells partially surrounded by pericytes (Figures 1 and 2). The cytoplasm of endothelial cells showed relative lucency with numerous free ribosomes, abundant intermediate filaments, a few rER, and a few mitochondria. The nuclei of the endothelial cells were large in comparison to the cytoplasm. These capillaries had relatively immature cell-tocell junctions near the lumen that form tight or gap junctions. The basement membrane was discontinuous. On day 10, more developed capillaries showing premature morphology were predominant (Figures 1 and 2). These had relatively large 
1176
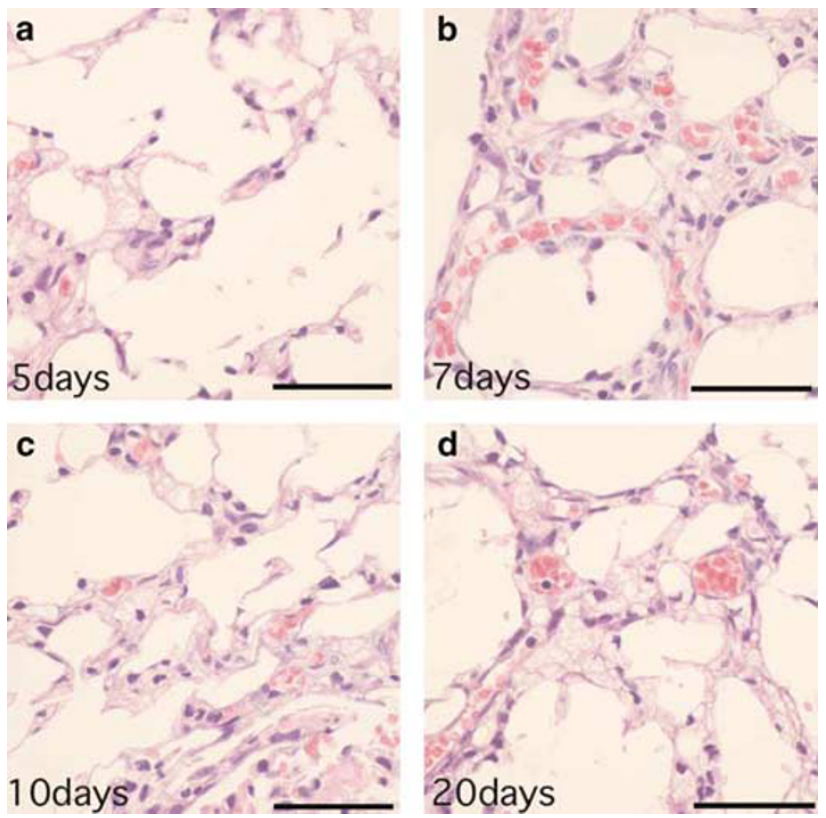

Figure 1 Light micrographs of the granulation tissues in subcutaneously implanted TGF discs. H\&E stain. Bars indicate $50 \mu \mathrm{m}$. (a) Day 5 after implantation: fibroblasts have migrated with a small number of newly formed capillaries. (b) Day 7 after implantation: many newly formed capillaries are observed with many fibroblasts. (c) Day 10 after implantation: many capillaries are observed. (d) Day 20 after implantation: many large capillaries are observed. Some vacuolated degenerating fibroblasts are also present.

endothelial cells containing a greater amount of rER, well-developed Golgi complexes, many ovoid or spherical mitochondria, and abundant plasmalemmal pits and vesicles. The basement membrane was discontinuous to continuous. Mature capillaries were observed on days 10-20 (Figures 1 and 2). These capillaries consisted of a relatively thin wall of endothelial cells, and Golgi apparatus and cytoplasmic vesicles had increased proportionately to the cell volume. Degenerated capillaries were also observed on day 20 (Figures 1 and 2). These capillaries consisted of quite thin and twisting walls of endothelial cells with decreased rER.

In the various developmental stages of the newly formed capillaries, many EPI were observed. An EPI is a combination of a pericyte cytoplasmic projection and a corresponding endothelial cytoplasmic indentation; the intercellular spaces of EPI lacked a basement membrane and plasmalemmal pits and vesicles located at the endothelial indentation cell membrane (Figures 1 and 2).

\section{Quantification of EPI}

The number of EPI per endothelial cell and pericyte was similar during the course of angiogenesis (Figure 3). The number of EPI per endothelial cell and pericyte was low on day 5 , and comparable to those of normal subcutaneous tissue (control). The number of EPI per endothelial cell then gradually increased in the following days to reach a peak on day 10, when it was significantly higher than that of control. The number of EPI per pericyte also significantly increased on days 5-10 compared to that of control and reached a peak on day 10 . The maximum number of EPI per endothelial cell and pericyte was about two to three times that of control. The number of EPI per endothelial cell and pericyte subsequently decreased and was similar to that of control by day 20 (Figure 3).

\section{Quantitative Study of Density and Size of Newly Formed Capillaries}

The number of capillaries per $1 \mathrm{~mm}^{2}$ was taken as the capillary density. The capillary density was low on day 5 , but it was significantly higher than that of control (Figure 3). After day 5, the capillary density increased sharply to reach a peak on day 7 . The maximum values of the capillary density were about four to five times that of control. Then, the density showed a significant decline on days 10-20. The capillary density on day 20 was similar to that of control, but the density on other days was significantly higher than that of the control (Figure 3). The outer diameter of the newly formed capillary was interpreted as the capillary size. Capillaries at days 5-7 were significantly smaller than those of control. Capillary size increased on days 10-20, and it was similar to that of control on day 20 (Figure 3).

\section{Quantification of Endothelial Cells and Pericytes}

The numbers of endothelial cells and pericytes per capillary cross-section were counted. The numbers changed significantly during the course of angiogenesis. The change in the number of endothelial cells during angiogenesis was found to be the inverse of the change in the number of pericytes (Figure 3). Endothelial cell numbers on days 5-7 were similar to those of control. The endothelial cell number had significantly decreased by day 10 , when it increased and on day 20 was similar to those of control (Figure 3 ). The number of pericytes on days $5-7$ was small and similar to those of control By day 10, the pericyte number had significantly increased, while it had decreased by day 20 and was similar to those of control (Figure 3).

\section{Localization of Ang-1, -2, Tie-2, and VEGF mRNA}

RNA in situ hybridization analysis revealed Ang-2 mRNA on the endothelial cell- and pericyte-like capillary walls (Figure 4). Tie-2 mRNA was observed on the endothelial cell-like luminal side of capillaries composed cells (Figure 4), while Ang-1 mRNA and VEGF mRNA were observed at pericyte-like perivascular mural cells (Figure 4). 

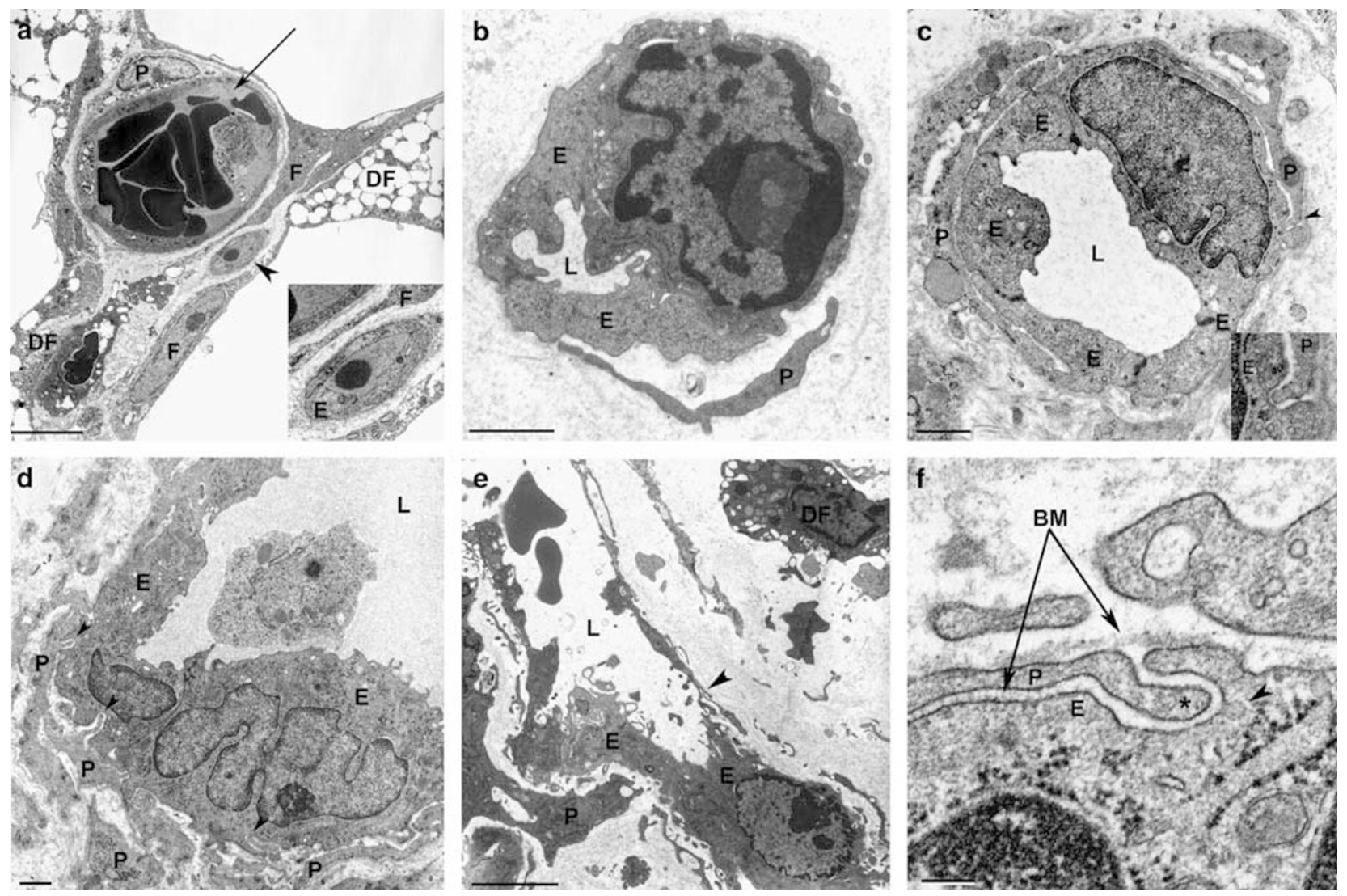

Figure 2 Electron micrographs of the newly formed capillaries in subcutaneously implanted TGF discs. E, endothelial cell; P, pericyte; L, capillary lumen; F, fibroblast; DF, vacuolated degenerated fibroblast; BM, basement membrane. (a) Granulation tissue on day 7 after implantation. Granulation tissue is composed of capillaries, fibroblasts, and vacuolated degenerating fibroblasts. A relatively mature capillary (arrow) composed of endothelial cells and pericytes that are surrounded by fibroblasts. A small, immature capillary is indicated by an arrowhead, and an enlargement is inserted in the lower right. Bar indicates $5 \mu \mathrm{m}$. (b) Immature capillary observed on day 5 after implantation. A pericyte is partially surrounded by endothelial cells. Bar indicates $1 \mu \mathrm{m}$. (c) A more-developed capillary observed on day 7 after implantation. Pericytes surround endothelial cells. EPI is indicated by an arrowhead, and an enlargement is inserted in the lower right. Bar indicates $1 \mu \mathrm{m}$. (d) Relatively mature capillary observed on day 10 after implantation. Pericytes surround endothelial cells. Three EPI are indicated by arrowheads. Bar indicates $1 \mu \mathrm{m}$. (e) Degenerated capillary observed on day 20 after implantation. EPI is indicated by an arrowhead. Bar indicates $5 \mu \mathrm{m}$. (f) High-power view of EPI observed on day 10 after implantation. EPI $\left({ }^{*}\right)$ is composed of a cytoplasmic projection and corresponding endothelial indentation and the lack of a basement membrane (BM) between pericyte and endothelial cells. A plasmalemmal pit locates at the endothelial cell indentation (arrowhead). Bar indicates $12 \mathrm{~nm}$.

\section{Light and Electron Microscopy Immunohistochemical Analyses of Ang-1, -2, Tie-2, and VEGF Protein}

To determine whether the localizations of Ang-1, -2, Tie-2, and VEGF mRNA correlated with the distribution of protein expression, immunohistochemical analysis was performed. Light and electron microscopy immunohistochemical analyses revealed that the expression of each protein was consistent with the pattern observed for each mRNA (Figures 5 and 6). Electron microscopy immunohistochemistry revealed that Ang-2 located at the cell membrane, plasmalemmal pits and vesicles, and cytoplasm of endothelial cells and pericytes of either immature or mature capillaries, and Tie-2 located at those of endothelial cells (Figure 6). Although Ang-1 located at pericytes in both premature and mature capillaries, it was not observed in immature capillaries (Figure 6). Moreover, Ang-1 was observed to localize intensely at the pericyte cytoplasmic projections of EPI and the cell membrane of the corresponding endothelial indentation including plasmalemmal pits and vesicles; localization was especially distinct on day 10 (Figure 6). On the other hand, VEGF was located at the cell membrane and cytoplasm of pericytes (Figure 6).

\section{Ang-1, -2, Tie-2, and VEGF mRNA Expression in TGP Discs}

The levels of Ang-1, -2, Tie-2, and VEGF mRNA expression were assessed by conventional and realtime quantitative RT-PCR. On days 5-7 after implantation, the expression of Ang-1 mRNA was significantly lower (0.4- to 0.5 -fold) than that of control (Figure 7). On day 10, Ang-1 mRNA had increased significantly (33-fold), and it had decreased (16-fold) by day 20 , but both were significantly higher than that of control (Figure 7). On days 

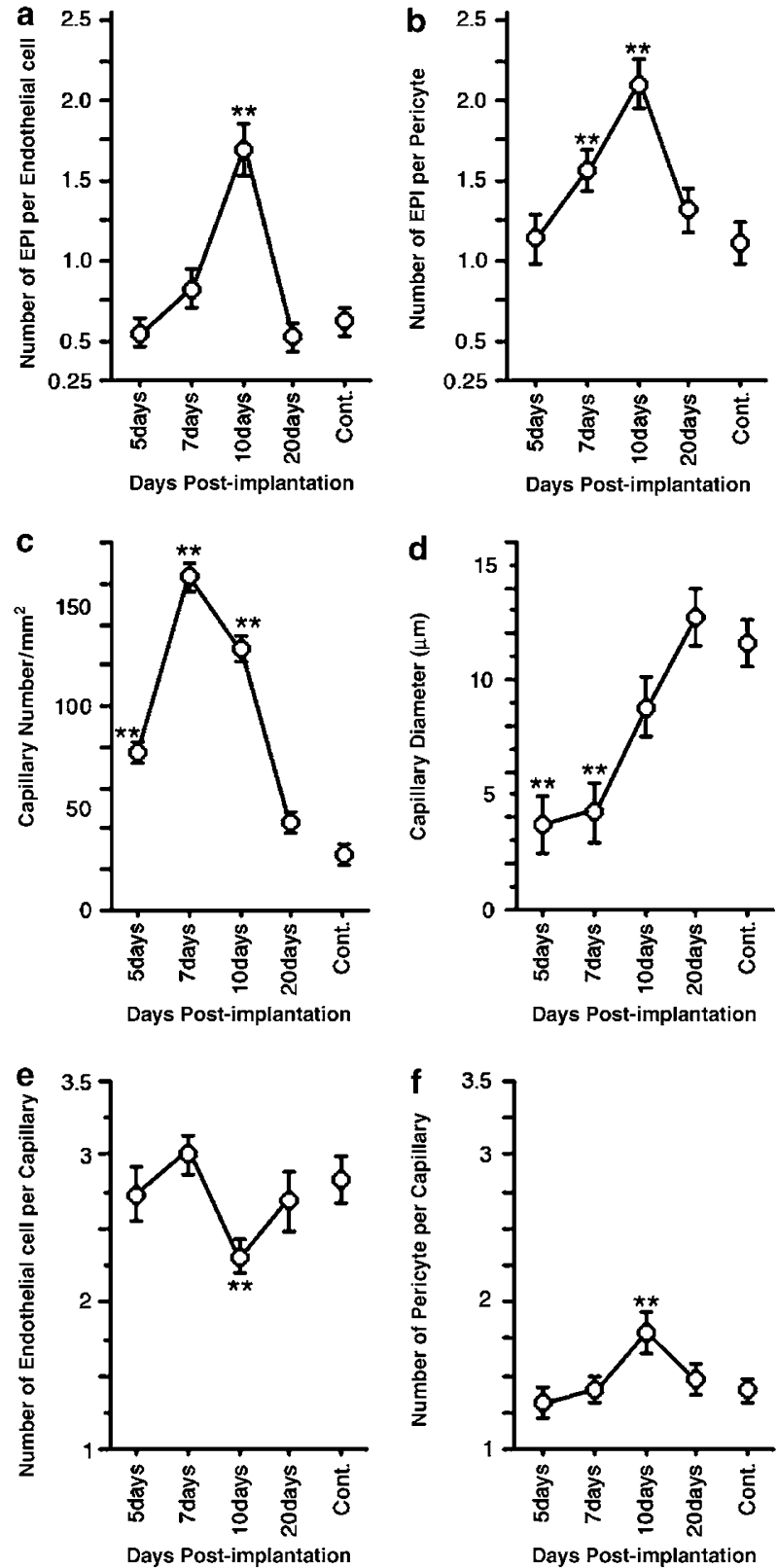

Figure 3 Time course of changes in EPI number, capillary density, capillary diameter, and number of endothelial cells and pericytes in TGF after subcutaneous implantation. 'control' indicates capillaries of normal (control) subcutaneous tissue. Values represent mean \pm s.e.m. EPI counts per endothelial cell (a) and pericyte (b) after implantation. The peak number of EPI is observed on day 10 after implantation $(\mathbf{a}, \mathbf{b})$. The density of newly formed capillaries per $\mathrm{mm}^{2}$ after implantation shows a peak on day 7 after implantation (c). The outer diameter $(\mu \mathrm{m})$ of a newly formed capillary shows the peak on day 20 after implantation (d). Numbers of endothelial cells (e) and pericytes (f) after implantation. On day 10 after implantation, the number of endothelial cells decrease and that of pericytes increase $(\mathbf{e}, \mathbf{f})$. $\left({ }^{* *}\right)$ Scheffé's $F$-test $P<0.01$.

5-20 after implantation, the expression of Ang-2 mRNA maintained a significantly high level (12- to 15-fold) compared to that of control (Figure 8), and the expression of Tie-2 mRNA maintained a low
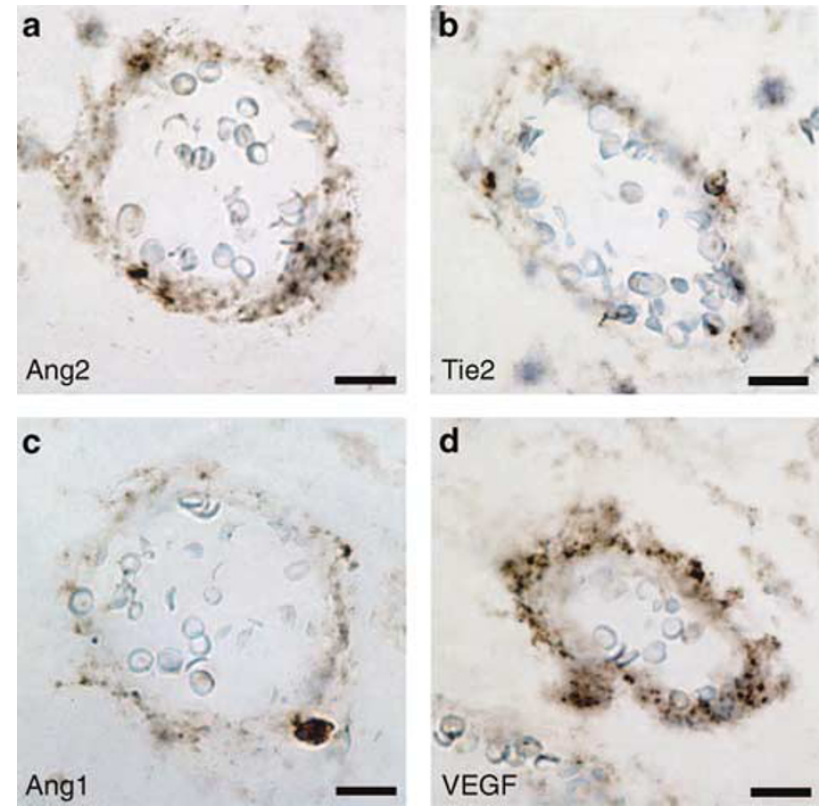

Figure 4 Hybridization of in situ Ang-1, -2, Tie-2, and VEGF mRNA in newly formed capillary in TGF disc on day 10 after subcutaneous implantation. Bars show $10 \mu \mathrm{m}$. (a) Ang-2 mRNA signals are present at capillary luminal and perivascular mural cells. (b) Tie-2 mRNA signals are present at capillary luminal cells. (c) Ang-1 mRNA signals are present at perivascular mural cells. (d) VEGF mRNA signals are present at perivascular mural cells.
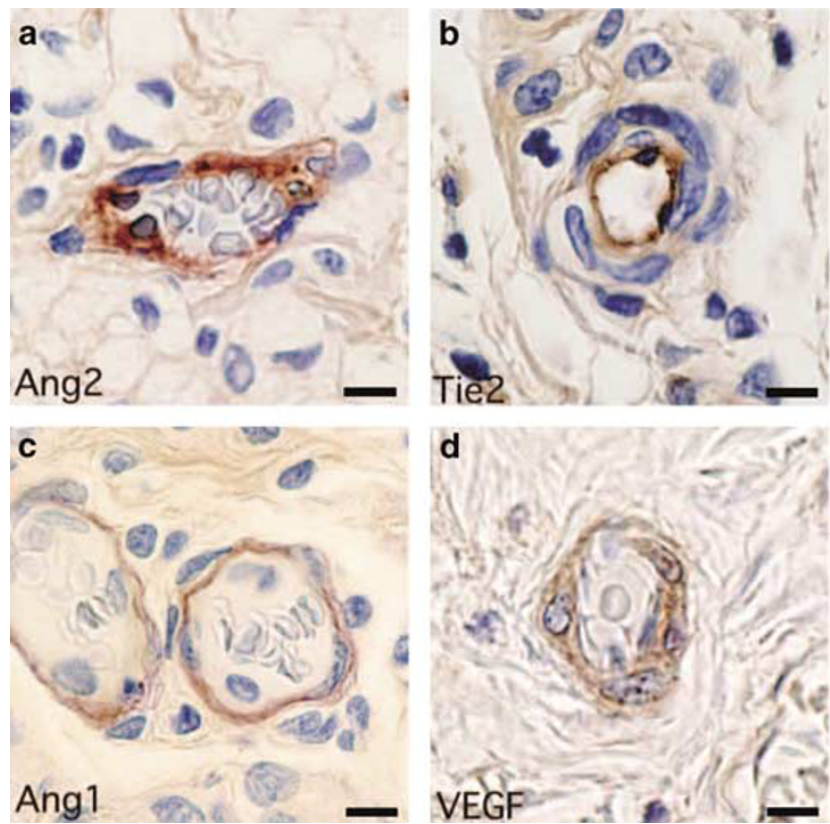

Figure 5 Immunohistochemical localization of Ang-1, -2, Tie-2, and VEGF in newly formed capillary in TGF disc on day 10 after subcutaneous implantation. Bars indicate $10 \mu \mathrm{m}$. (a) Immunoreactive deposits of Ang-2 are present at endothelial cells and pericytes. (b) Immunoreactive deposits of Tie-2 are present at endothelial cells. (c) Immunoreactive deposits of Ang-1 are present at pericytes. (d) Immunoreactive deposits of VEGF are present at pericytes. 

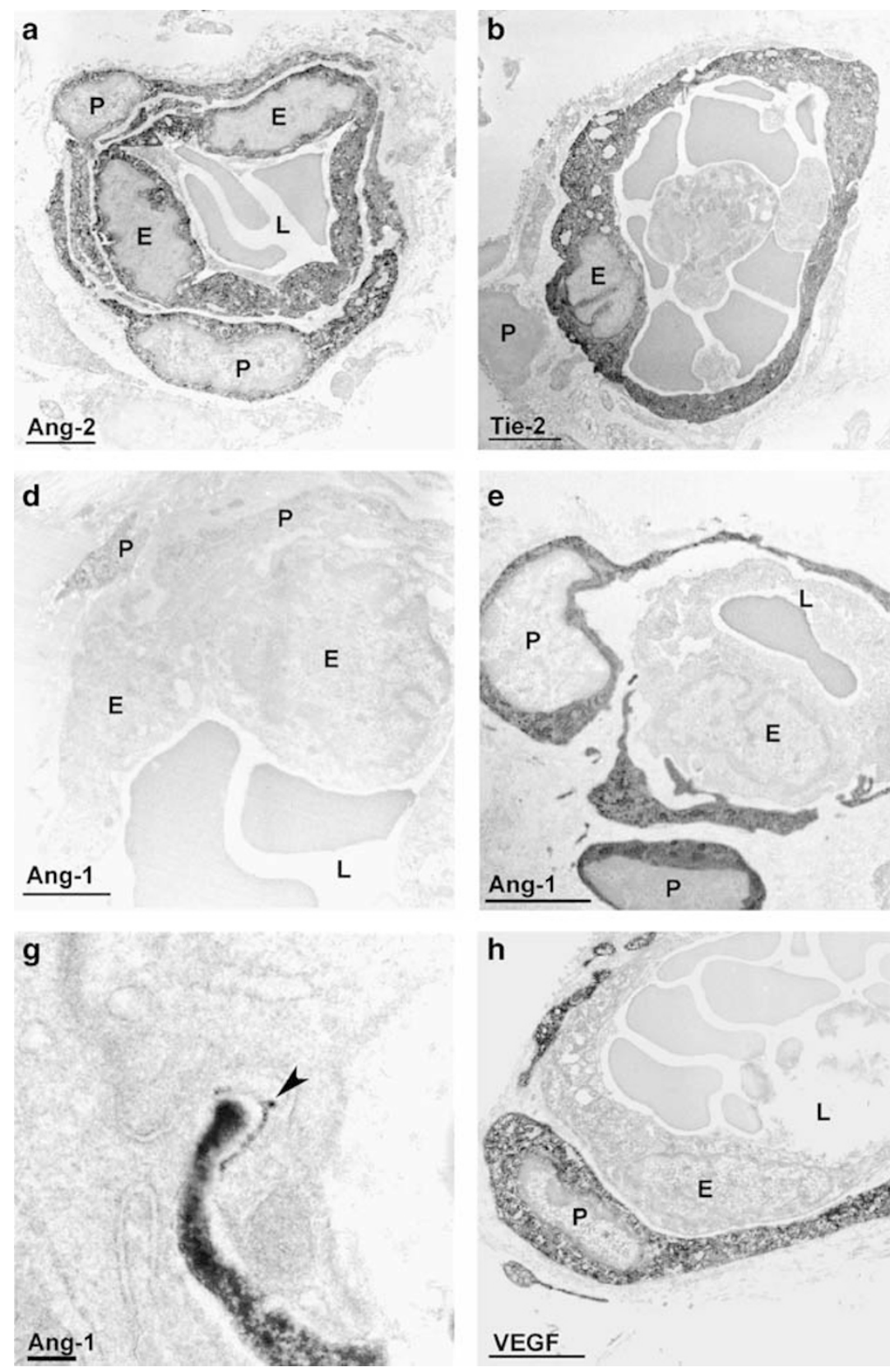
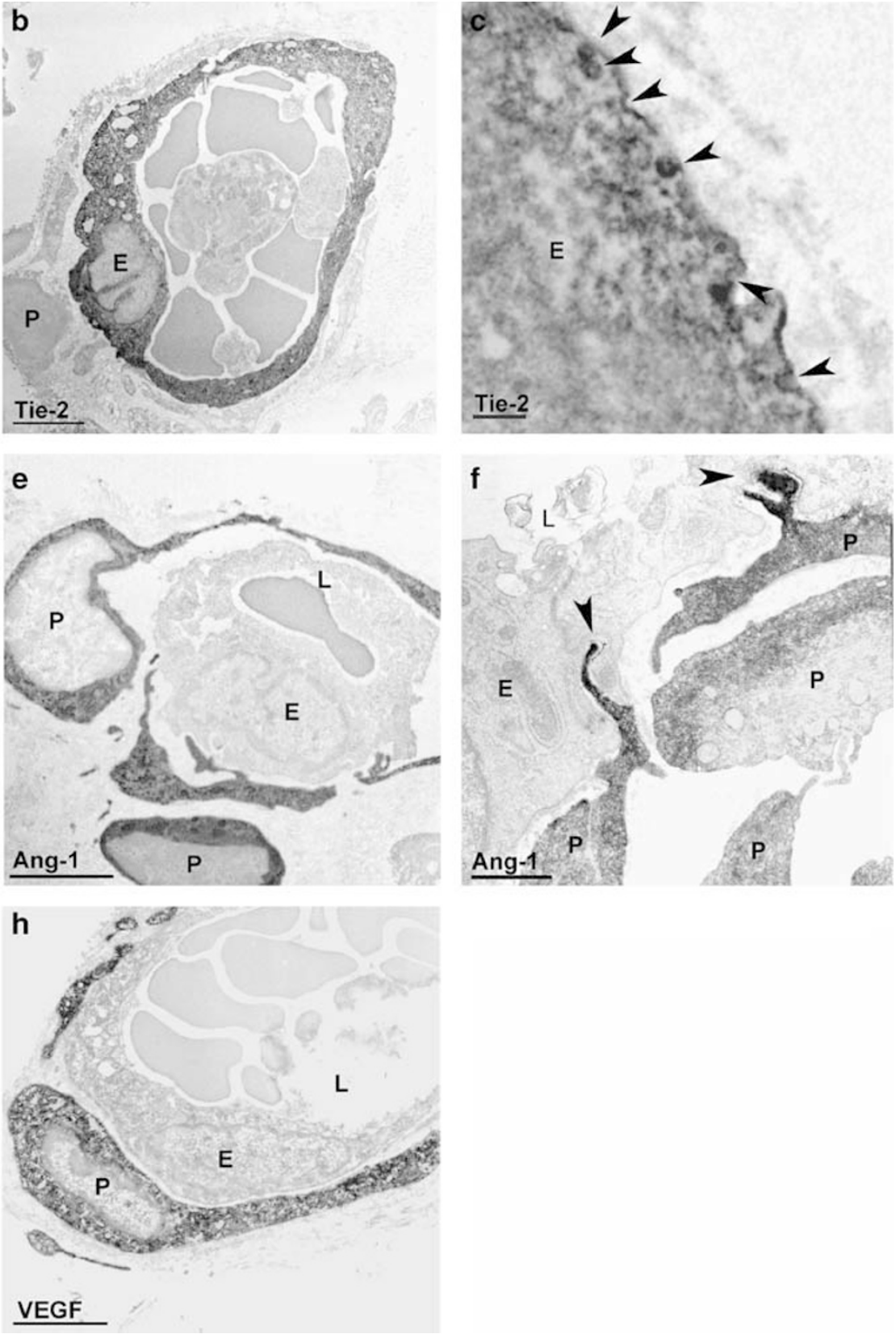

Figure 6 Immunoelectron micrographs of Ang-1, -2, Tie-2, and VEGF in newly formed capillaries in subcutaneously implanted TGF discs. E, endothelial cell; P, pericyte; L, capillary lumen. (a) Immunoelectron micrograph of Ang-2 on day 10 after implantation. Immunoreactive deposits are present in the cytoplasm of endothelial cells and pericytes. Bar indicates $2.5 \mu \mathrm{m}$. (b) Immunoelectron micrograph of Tie-2 on day 10 after implantation. Immunoreactive deposits are present in the cytoplasm of endothelial cells. Bar indicates $3.3 \mu \mathrm{m}$. (c) High power view of immunoelectron micrograph of Tie-2 on the vasolateral side of endothelial cells on day 10 after implantation. Some plasmalemmal pits and vesicles show dense immunoreactive deposits (arrowheads). Bar indicates $12 \mathrm{~nm}$. (d) Immunoelectron micrograph of Ang-1 on day 7 after implantation. No immunoreactive deposits are observed at either pericytes or endothelial cells. Bar indicates $1.6 \mu \mathrm{m}$. (e) Immunoelectron micrograph of Ang-1 on day 10 after implantation. Immunoreactive deposits are present in the cytoplasm of pericytes. Bar indicates $3.3 \mu \mathrm{m}$. (f) Immunoelectron micrograph of Ang-1 on day 10 after implantation. Immunoreactive deposits are densely present in the pericyte cytoplasmic projection of EPI (arrowheads). Bar indicates $0.1 \mu \mathrm{m}$. (g) Highpower view of immuneoelectron micrograph of Ang-1 at EPI. Immunoreactive deposits are observed at a pericyte cytoplasmic projection of EPI and cell membrane of the corresponding endothelial indentation (arrowhead). Bar indicates $12 \mathrm{~nm}$. (h) Immunoelectron micrograph of VEGF on day 10 after implantation. Immunoreactive deposits are present in the cytoplasm of pericytes. Bar indicates $3.3 \mu \mathrm{m}$.

level similar to that of control (Figure 9). On days 5-7 after implantation, the expression of VEGF mRNA was significantly higher (28- to 30 -fold) than that of control, and it reached a peak on day 10 (38-fold). The expression of VEGF mRNA had decreased sharply on day 20, when it was similar to that of control (Figure 10). 
a Ang-

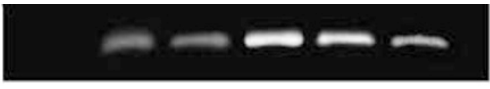

GAPDH

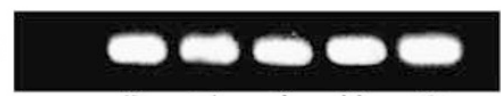

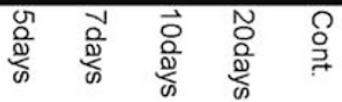

b

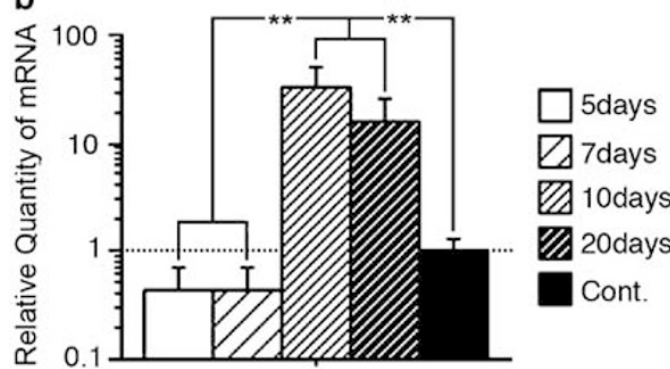

Figure 7 Time course of changes in Ang-1 mRNA expression in TGF after subcutaneous implantation. 'control' indicates capillaries of normal (control) subcutaneous tissue. (a) Semiquantitative PCR indicates high Ang-1 mRNA on days 10-20 after implantation. (b) Real-time PCR for Angi-1 mRNA. The expression level on days 10-20 is significantly higher than that on days $5-7$, which is significantly lower than that of the control Values represent mean \pm s.d. ${ }^{* *}$ ) Scheffé's $F$-test $P<0.01$.

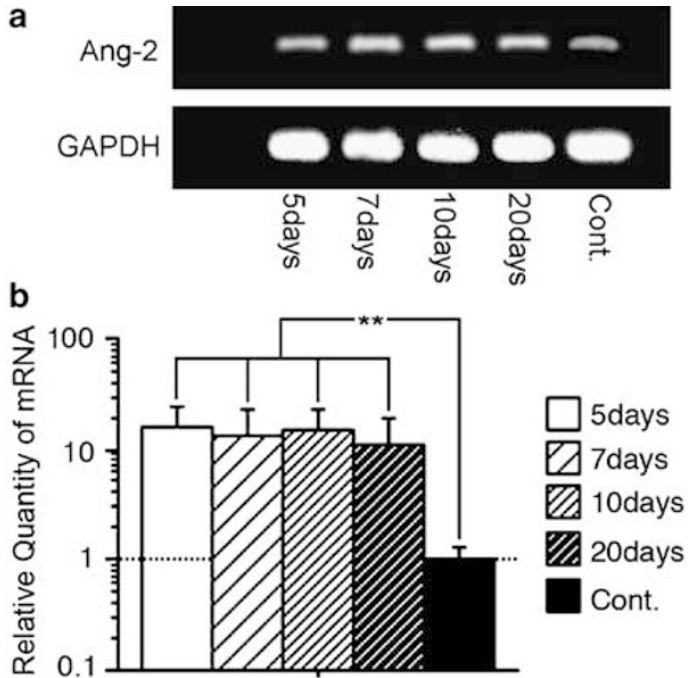

Figure 8 Time course of changes in Ang-2 mRNA expression in TGF after subcutaneous implantation. 'control' indicates capillaries of normal (control) subcutaneous tissue. (a) Semiquantitative PCR indicates higher Ang-2 mRNA on days 5-20 after implantation compared to 'control'. (b) Real-time PCR for Angi-2 mRNA. The expression level on days $5-20$ is significantly higher than that of control values represent mean \pm s.d. $\left(^{* *}\right)$ Scheffé's $F$-test $P<0.01$.

\section{Ang-1, -2, Tie-2, and VEGF Protein Expression in TGP Discs}

To determine whether the mRNA modulation of Ang-1, -2, Tie-2, and VEGF correlated with changes in protein expression, Western blotting was performed. The protein expression was qualitatively

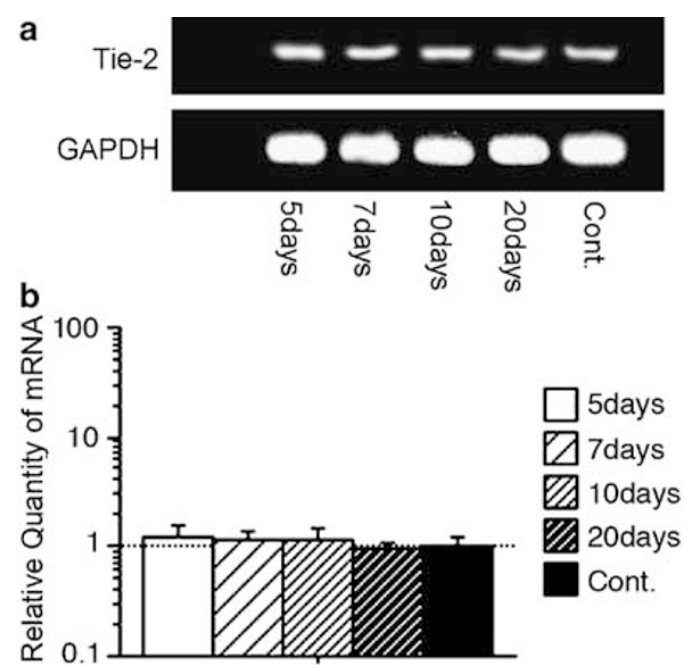

Figure 9 Time course of changes in Tie-2 mRNA expression in TGF after subcutaneous implantation. 'control' indicates capillaries of normal (control) subcutaneous tissue. (a) Semiquantitative PCR showing that Tie-2 mRNA expression on days 5-20 after implantation is similar to that of control. (b) Real-time PCR for Tie-2 mRNA. The expression level on days $5-20$ is similar to that of control values represent mean \pm s.d.

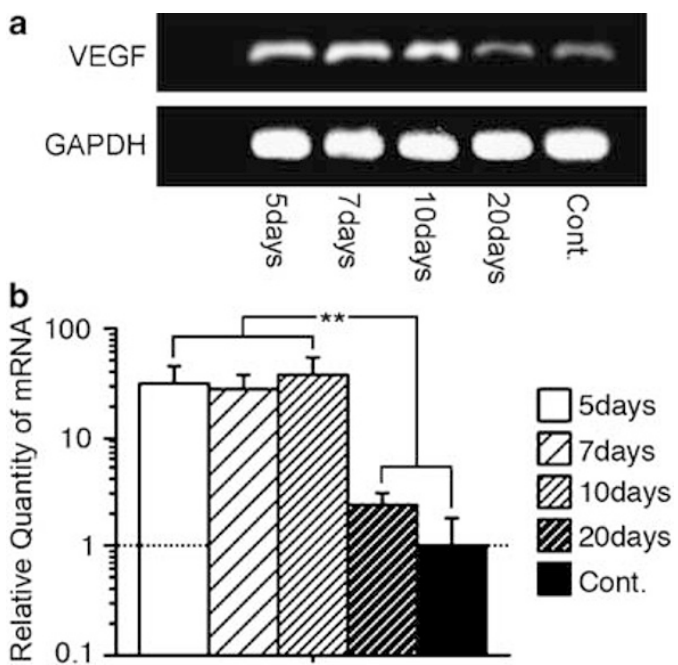

Figure 10 Time course of changes in VEGF mRNA expression in TGF after subcutaneous implantation. 'Control' indicates capillaries of normal (control) subcutaneous tissue. (a) Semiquantitative PCR showing high VEGF mRNA expression on days 5-10 after implantation. (b) Real-time PCR for VEGF mRNA. The expression on days $5-10$ is significantly higher than that of control, and that on day 20 is similar to that of control values represent mean \pm s.d. ${ }^{* *}$ ) Scheffé's $F$-test $P<0.01$.

consistent with the patterns observed for each mRNA (Figure 11).

\section{Discussion}

Constitutive expression of Ang-2 by normal tissue stabilizes existing blood vessels ${ }^{38,39}$ because the ratio of Ang-1 to Ang-2 appears to control the switch to microvessel remodeling. ${ }^{4-51}$ Recently, it has been 
a
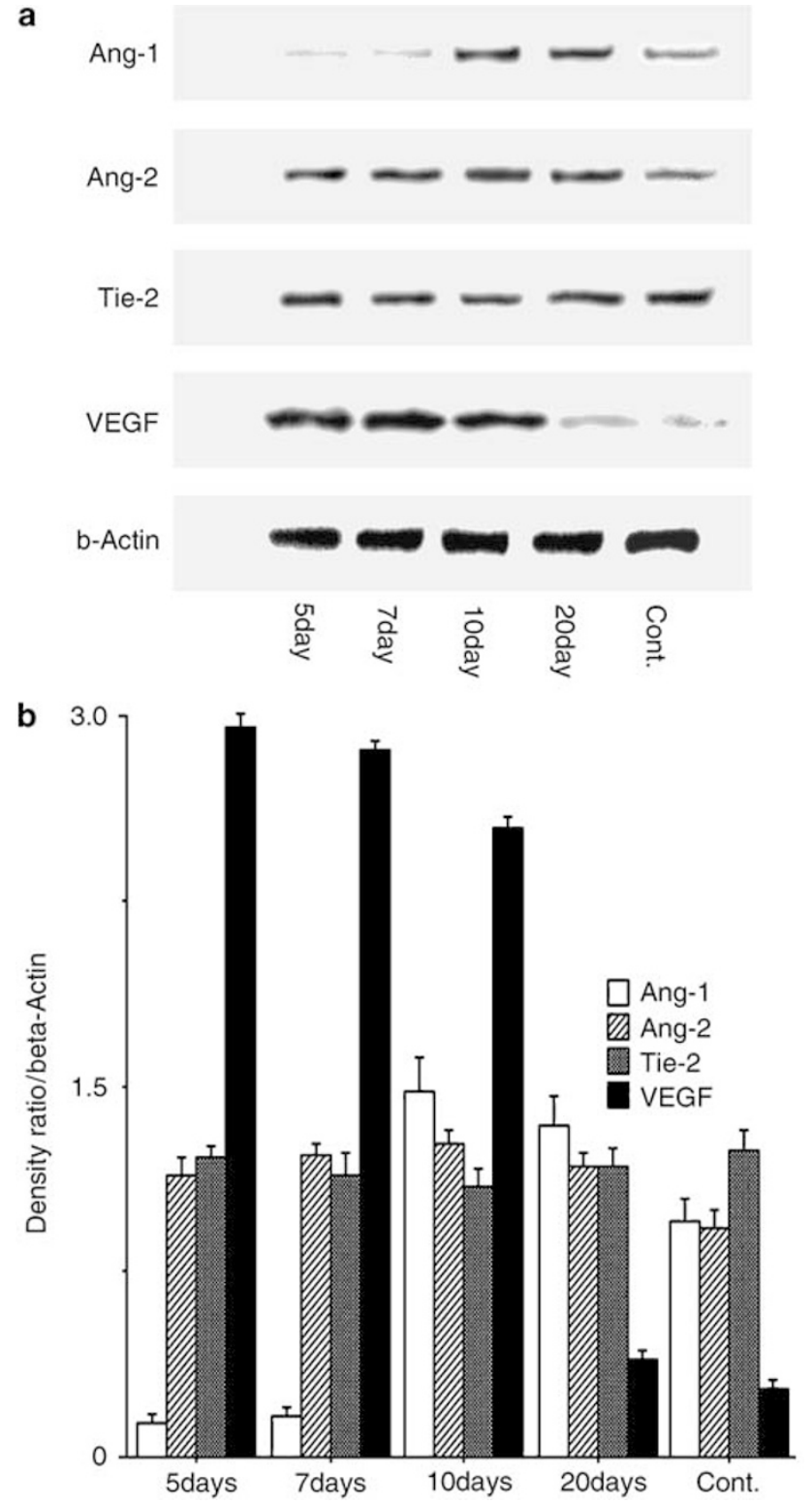

Figure 11 Western blots of Ang-1, -2, Tie-2, and VEGF in TGF after subcutaneous implantation. (a) Shows representative Western blot bands, and (b) shows the density ratio to beta-actin; results were obtained by screening samples from five rats on each day. Values represent mean \pm s.d.

reported that an equal amount of Ang-1 can rescue Ang-2-mediated effects, indicating that a balance between the two factors regulates the quiescence and responsiveness of microvessels. ${ }^{52}$ The present study shows that the angiogenic phase might be initiated by increases in Ang-2 and VEGF, while the microvessel maturation phase might be initiated by a relative increase in Ang-1 and a decrease in VEGF. It has been postulated that the angiogenic process of the present TGP in vivo angiogenic model depends on a change in the Ang-1 level. Further studies will be designed to test this hypothesis directly.

In this study, Tie-2 was observed to localize at the cell membrane, plasmalemmal pits and vesicles, and cytoplasm of endothelial cells. These results agree with most of the literature published concerning this receptor system. ${ }^{53,54}$ Endothelial cells have been described as the primary source for Ang-2, suggesting that it might act as an autocrine regulator of endothelial cell functions, ${ }^{23,55-61}$ while in vitro data has suggested that Ang-2 expression increases in pericytes under hyperglycemic conditions. ${ }^{61}$ The present in vivo study revealed that Ang-2 localized at endothelial cells and pericytes of both immature and mature microvessels, while in vitro studies have produced evidence consistent with the hypothesis that Ang-1 is produced by pericytes and smooth muscle cells, and might act in a paracrine manner for Tie-2-expressing endothelial cells. ${ }^{22,23,55,57,62,63}$ Whether pericytes express Ang-1 in vivo has been hard to demonstrate, but cell sorting experiments suggest they do. ${ }^{64}$ Moreover, a recent study using in situ hybridization demonstrated Ang-1 mRNA expression by perivascular cells during microvessel maturation, but the limited resolution of light microscopy presented made it difficult to distinguish pericytes. ${ }^{65}$ We also observed Ang-1 mRNA expression by pericyte-like perivascular mural cells by light microscopic in situ hybridization, while the present study using electron microscopy immunohistochemistry clearly revealed that pericytes were the primary source of Ang-1. Moreover, recent studies have shown that pericytes are induced to express VEGF, which might contribute to development of the microvessel itself. ${ }^{7,64,66-70}$ In this study, it was clearly shown by electron microscopy immunohistochemistry that pericytes express VEGF.

EPI are sites of intimate contact between pericytes and endothelial cells by interdigitation. ${ }^{8-10}$ We have shown in the present study and a previous report that EPI are predominate following the active microvessel proliferation stage in the angiogenic process. ${ }^{14}$ Physical contact between pericytes and endothelial cells has been reported to be necessary to prevent angiogenesis with inhibition of endothelial cell proliferation. , $^{3,71,72}$ Further, we have demonstrated that EPIs acting as a pathway for the EGF/EGF-receptor system might activate pericytes for capillary maturation. ${ }^{12,13}$ We have also reported that EPI activation of latent TGF-beta might inhibit endothelial cell proliferation, and promote capillary maturation and degeneration. ${ }^{19}$ It has been reported that reduced expression of VEGF and enhanced expression of Ang-1 might contribute to the formation of leakage-resistant blood vessels. ${ }^{34,73}$ Recently, we demonstrated that the direct injection of an antibody neutralizing VEGF induces a significant decrease in the number of EPI and an increase in the number of nonleaky capillaries in an $N$-butyl- $N$-(4hydroxybutyl) nitrosamine-induced rat bladder carcinoma model. ${ }^{15}$ EPI have been difficult structures to study by light microscopy. The present study revealed that Ang-1 is expressed ultrastructurally by pericytes, especially at the pericyte cytoplasmic projections of EPI and cell membranes of the 
corresponding endothelial indentation. As Ang-1 and Tie-2 appear to be required for communication of endothelial cells with pericytes, EPI might, in part, act as a pathway for the Ang-1/Tie-2 system to stabilize microvessels.

\section{Acknowledgements}

This study was supported by Grants-in-aid \#009660332, \#12660278, and \#15580267 from the Ministry of Education, Science and Culture, Japan. We are grateful to $M$ Takagi, $M$ Arima, and $M$ Shugimoto for technical assistance, and Katherine Ono for critical reading and editing of the paper.

\section{References}

1 Risau W. Mechanisms of angiogenesis. Nature (London) 1997;386:671-674.

2 Ramsauer M, D'Amore PA. Getting Tie(2)d up in angiogenesis. J Clin Invest 2002;110:1615-1617.

3 Orlidge A, D'Amore PA. Inhibition of capillary endothelial cell growth by pericytes and smooth muscle cells. J Cell Biol 1987;105:1455-1462.

4 Hirschi KK, Rohovsky SA, D’Amore PA. PDGF, TGF-b and heterotypic cell-cell interactions mediate endothelial cell-induced recruitment of $10 \mathrm{~T} 1 / 2$ cells and their differentiation to smooth muscle cell fate. J Cell Biol 1998;141:805-814.

5 Benjamin LE, Hemo I, Keshet E. A plasticity window for blood vessel remodelling is defined by pericyte coverage of the preformed endothelial network and is regulated by PDGF-B and VEGF. Development 1998;125:1591-1598.

6 Nguyen LL, D'Amore PA. Cellular interactions in vascular growth and differentiation. Int Rev Cytol 2001;204:1-48.

7 Gerhardt H, Betsholz C. Endothelial-pericyte interactions in angiogenesis. Cell Tissue Res 2003;314:15-23.

8 Wakui S. Two and three dimensional ultrastructural observation of two cell angiogenesis in human granulation tissue. Virchow Arch B 1988;56:127-139.

9 Wakui S, Furusato M, Hasumura M, et al. Two and three dimensional ultrastructure of endothelium and pericyte interdigitation in capillary of human granulation tissue. J Electron Microsc 1989;38:136-142.

10 Furusato M, Wakui S, Suzuki M, et al. Three dimensional ultrastructural distribution of cytoplasmic interdigitation between endothelium and pericyte of capillary in human granulation tissue by serial reconstruction method. J Electron Microsc 1990;39: 86-91.

11 Wakui S, Furusato M, Nikaido T, et al. The ultrastructural localization of fibronectin and laminin in human granulation tissue, with special reference to capillary development. Cell Struct Funct 1990;15: 201-210.

12 Wakui S, Furusato M, Tanaka M, et al. Endothelium and pericyte interdigitation: pathway for epidermal growth factor? Microvasc Res 1990;40:285-291.

13 Wakui S. Epidermal growth factor receptor at endothelial cell and pericyte interdigitation in human granulation tissue. Microvasc Res 1992;44:255-262.
14 Wakui S, Furusato M, Ohshige H, et al. Endothelialpericyte interdigitations in rat subcutaneous disc implanted angiogenesis. Microvasc Res 1993;46:19-27.

15 Wakui S, Muto T, Ohshige $\mathrm{H}$, et al. Capillary fenestration in BBN-induced rat bladder carcinoma is promoted by vascular endothelial growth factor. J Toxicol Pathol 2000;13:219-224.

16 Povlishock JT, Martinez AJ, Moossy J. The fine structure of blood vessels of the telecephalic germinal matrix in the human fetus. Am J Anat 1977;149: 439-452.

17 Leson TS. Rat retinal blood vessels. Can J Opthalmol 1979;14:21-28.

18 Allsopp G, Gamble HJ. An electron microscopic study of the pericyte of the developing capillaries in human fetal brain and muscle. J Anat 1979;128:155-168.

19 Wakui S, Furusato M, Muto T, et al. TGF-beta and plasminogen activator at endothelial cell and pericyte interdigitation in human granulation tissue. Microvasc Res 1997;54:262-269.

20 Dumont DJ, Yamaguchi TP, Conlon RA, et al. Tek, a novel tyrosine kinase gene located on mouse chromosome 4, is expressed in endothelial cells and their presumptive precursors. Oncogene 1992;7:1471-1480.

21 Sato TN, Qin Y, Kozak CA, et al. Tie-1 and tie-2 define another class of putative receptor tyrosine kinase genes expressed in early embryonic vascular system. Proc Natl Acad Sci USA 1993;90:9355-9358.

22 Davis S, Aldrich TH, Jones PF, et al. Isolation of angiopoietin-1, a ligand for the TIE2 receptor, by secretion-trap expression cloning. Cell 1996;87: 1161-1169.

23 Maisonpierre PC, Suri C, Jones PF, et al. Angiopoietin2, a natural antagonist for Tie2 that disrupts in vivo angiogenesis. Science 1997;277:55-60.

24 Asahara T, Chen D, Takahashi T, et al. Tie2 receptor ligands, angiopoietin-1 and angiopoietin-2, modulate VEGF-induced postnatal neovascularization. Circ Res 1998;83:233-240.

25 Koblizek TI, Weiss C, Yancopoulos GD, et al. Angiopoietin-1 induces sprouting angiogenesis in vitro. Curr Biol 1998;8:529-532.

26 Lauren J, Gunji Y, Alitalo K. Is angiopoietin-2 necessary for the initiation of tumor angiogenesis? Am J Pathol 1998;153:1333-1339.

27 Peters KG, Coogan A, Berry D, et al. Expression of Tie2/Tek in breast tumour vasculature provides a new marker for evaluation of tumour angiogenesis. $\mathrm{Br} \mathrm{J}$ Cancer 1998;77:51-56.

28 Beck H, Acker T, Wiessner C, et al. Expression of angiopoietin-1, angiopoietin-2, and tie receptors after middle cerebral artery occlusion in the rat. Am J Pathol 2000;157:1473-1783.

29 Kim I, Kim HG, So JN, et al. Angiopoietin-1 regulates endothelial cell survival through the phosphatidylinositol 3'-kinase/Akt signal transduction pathway. Circ Res 2000;86:24-29.

30 Yancopoulos GD, Davis S, Gale NW, et al. Vascularspecific growth factors and blood vessel formation. Nature (London) 2000;407:242-248.

31 Schnurch H, Risau W. Expression of tie-2, a member of a novel family of receptor tyrosine kinases, in the endothelial cell lineage. Development 1993;119:957-968.

32 Maisonpierre PC, Goldfarb M, Yancopoulos GD, et al. Distinct rat genes with related profiles of expression define a TIE receptor tyrosine kinase dimaly. Oncogene 1993;8:1631-1637. 
33 Sato TN, Tozawa Y, Deutsch U, et al. Distinct roles of the receptor tyrosine kinases Tie-1 and Tie-2 in blood vessel formation. Nature (London) 1995;376:70-74.

34 Suri C, Jones PF, Patan S, et al. Requisite role of angiopoietin-1, a ligand for the TIE2 receptor, during embryonic angiogenesis. Cell 1996;87:1171-1180.

35 Korhonen J, Polvi A, Partanen J, et al. The mouse tie receptor tyrosine kinase gene: expression during embryonic angiogenesis. Oncogene 1994;9:395-403.

36 Dumont DJ, Gradwohl G, Fong GH, et al. Dominatnegative and targeted null mutations in the endothelial receptor tyrosine kinase, tek, reveal a critical role in vasculogenesis of the embryo. Genes Dev 1994;8: 1897-1909.

37 Hanahan D. Signaling vascular morphogenesis and maintenance. Science 1997;277:48-50.

38 Teichert-Kuliszewska K, Maisonpierre PC, Jones N, et al. Biological action of angiopoietin-2 in a fibrin matrix model of angiogenesis is associated with activation of Tie2. Carciovasc Res 2001;49:659-670.

39 Lobov IB, Brooks PC, Lang RA. Angiopoietin-2 displays VEGF-dependent modulation of capillary structure and endothelial cell survival in vivo. Proc Natl Acad Sci USA 2002;99:11205-11210.

40 Madhavan HN, Malathi J, Joseph RP, et al. A study of the growth continuous culture cell lines embedded in Mebio gel. Current Sci 2004;87:1275-1277.

41 Yoshioka H, Mikami M, Mori Y. A synthetic hydrogel with thermoreversible gelation. I. Prepation and rheological properties J.M.S. Pure Appl Chem 1994;31: 113-120.

42 Yoshioka H, Mori Y, Cushman JA. A synthetic hydrogel with thermoreversible gelation. III. An NMR study of the sol-gel transition. Polym Adv Technol 1994;5:122-127.

43 Leeson TS. Rat retinal blood vessels. Can J Opthalmol 1979;14:21-28.

44 Nakane PK, Kawaoi A. Peroxidase-labeled antibody. A new method of conjugation. J Histochem Cytochem 1974;22:1084-1091.

45 Lloyd PG, Prior BM, Yang HT, et al. Angiogenic growth factor expression in rat skeletal muscle in response to exercise training. Am J Physiol Heart Circ Physiol 2003;284:H1668-H1678.

46 Willy LA, Brekowitz BA, Steinle JJ. Superior cervical ganlinoectomty induces changes in growth factor expression in the rat retina. Invest. Ophthalmol visual Sci 2006;47:439-443.

47 Farrar CA, Zhou W, Lin T, et al. Local extravascular pool of C3 is a determinant of postischemic actute renal failure. FASEB J 2006;20:217-226.

48 Wakui S, Yokoo K, Takahashi H, et al. Prenatal 3,3',4,4',5-pentachlorobiphenyl exposure modulates induction of rat hepatic CYP 1A1, 1B1 and AhR by 7,12-dimethylbenz[a]anthracene. Toxicol Appl Pharmacol 2006;210:200-211.

49 Carmeliet P. Angiogenesis in health and disease. Nat Med 2003;9:653-660.

50 Jain RK. Molecular regulation of vessel maturation. Nat Med 2003;9:685-693.

51 Fiedler U, Scharpfenecker M, Koidl S, et al. The Tie-2 ligand angiopoietin-2 is stored in and rapidly released upon stimulation from endothelial cell Weibel-Palade bodies. Blood 2004;103:4150-4156.

52 Scharpfenecker M, Fiedler U, Reiss Y, et al. The tie-2 ligand angiopoietin-2 destabilizes quiescent endothelium through an internal autocrine loop mechanism. J Cell Sci 2005;118:771-780.
53 Zhang EG, Smith SK, Baker PN, et al. The regulation and localization of angiopoietin-1, 2 and their receptor Tie2 in normal and pathologic human placentae. Mol Med 2001;7:624-635.

54 Yoon MJ, Cho CH, Lee CS, et al. Localization of Tie2 and phospholipase $\mathrm{D}$ in endothelial caveolae is involved in angiopoietin-1-induced MEK/ERK phosphorylation and migration in endothelial cells. Biochem Biophys Res Commun 2003;308:101-105.

55 Thurston G, Rudge JS, Ioffe E, et al. Angiopoietin-1 protects the adult vasculature against plasma leakage. Nat Med 2000;6:460-463.

56 Kim I, Moon SO, Park SK, et al. Angiopoieti-1 reduces VEGF-stimulated leukocyte adhesion to endothelial cells by reducing ICAM-1, VCAM-1, and E-selectin expression. Circ Res 2001;89:477-479.

57 Mandriota SJ, Pepper MS. Regulation of angiopoietin-2 mRNA levels in bovine microvascular endothelial cells by cytokines and hypoxia. Circ Res 1998;83:852-859.

58 Hackett SF, Ozaki H, Strauss RW, et al. Angiopoietin 2 expression in the retina: upregulation during physiologic and pathologic neovascularization. J Cell Physiol 2000;184:275-284

59 Gale NW, Thurston G, Hackett SF, et al. Angiopoietin-2 is required for postnatal angiogenesis and lymphatic patterning, and only the latter role is rescued by angiopoietin-1. Dev Cell 2002;3:411-423.

60 Huang YD, Li JJ, Hu L, et al. Thrombin induces increased expression and secretion of angiopoietin-2 from human umbilical vein endothelial cells. Blood 2002;99:1646-1650.

61 Zhang L, Yang N, Park JW, et al. Tumor-derived vascular endothelial growth factor up-regulates angiopoietin-2 in host endothelium and destabilized host vasculature supporting angiogenesis in ovarian cancer. Cancer Res 2003;63:3403-3412.

62 Kim I, Oh JL, Ryu YS, et al. Angiopoietin-1 negatively regulates expression and activity of tissue factor in endothelial cells. FASEB J 2002;16:126-128.

63 Brown C, Gaspar JP, Psttit A, et al. ESE-a is a novel transcriptional mediator of angiopoietin-1 expression in the setting of inflammation. J Biol Chem 2004;279:12794-12803.

64 Sundberg C, Kowanetz M, Brown LF, et al. Stable expression of angiopoietin-1 and other markers by cultured pericytes: phenotypic similarities to a subpopulation of cells in maturing vessels during later stages of angiogenesis in vivo. Lab Invest 2002;82: 387-401.

65 Erber R, Thurnher A, Katsen AD, et al. Combined inhibition of VEGF-and PDGF signaling enforces tumor vessel regression by interfering with pericytemediated endothelial cell survival mechanisms. FASEB J 2003;18:338-340.

66 Antonelli-Orlidge A, Saunders KB, Smith SR, et al. An activated form of transforming growth factor beta is produced by cocultures of endothelial cells and pericytes. Proc Natl Acad Sci USA 1989;86:4544-4548.

67 Nomura M, Yamagishi S, Harada S, et al. Possible participation of autocrine and paracrine vascular endothelial growth factors in hypoxia-induced proliferation of endothelial cells and pericytes. J Biol Chem 1995;270:28316-28324.

68 Reynolds LP, Grazul-Bilska AT, Redmer DA. Angiogenesis in the corpus luterum. Endocrine 2000;12:1-9.

69 Ramsauer M, D’Amore PA. Getting Tie(2)d up in angiogenesis. J Clin Invest 2002;110:1615-1617. 
70 Witmer AN, Dai J, Weich HA, et al. Expression of vascular endothelial growth factor receptors 1,2 , and 3 in quirescent endothelia. J Histochem Cytochem 2002;50:767-778.

71 Cogan DG, Toussaint D, Kuwabara T. Retinal vascular patterns IV. diabetic retinopathy. Arch Ophthalmol 1961;66:336-378.

72 Hirschi KK, Rohovsky SA, Beck LH, et al. Endothelial cells modulate the proliferation of mural cell precursors via platelet-derived growth factor-BB and heterotypic cell contact. Circ Res 1999;84:298-305.

73 Thurston G, Suri C, Smith K, et al. Leakage-resistant blood vessels in mice transgenically overexpressing angiopoietin-1. Science 1999;286:2511-2514. 